endpoints were the occurrence of non-serious adverse events (AEs) of at least moderate severity and serious AEs (SAEs), including macrophage activation syndrome (MAS), and the duration of anakinra treatment with reasons for discontinuation. All endpoints were analyzed overall, by 6 month-time windows and in different treatment sets represented by those patients continuously treated with anakinra for at least 12, 18 and 24 months (set-12, -18, -24, respectively). Results: 306 patients were enrolled. $46 \%, 34 \%$ and $28 \%$ of them had been treated for at least 12, 18 and 24 months, respectively. 201 AEs, mostly represented by infections, were reported for 509.3 patient-years (py) with an overall incidence rate (IR) of $39.5 / 100$ py. Among 56 SAEs (IR 11.0/100 py), (Table 1) $23.2 \%$ were infections and $19.6 \%$ MAS episodes. The IR of AEs was higher during the first 6 months of anakinra, followed by decreasing IR in the different longterm treatment sets. Treatment discontinuation occurred in $76 \%$ of patients, most in the first 6 months, due to inefficacy (43\%), remission (31\%) or AEs/intolerance (15\%). No deaths or malignancies occurred during anakinra treatment.

Table 1. Number of SAEs and incidence rates $(95 \% \mathrm{Cl})$ by overall PT decreasing order and time window in the complete set (events with a frequency $>1$ by overall SOC and $>1$ by overall PT were reported) Only time windows $<13$ months were reported in the present table.

\begin{tabular}{|c|c|c|c|c|c|c|c|}
\hline & \multirow{2}{*}{$\frac{\text { Time window }}{\mathrm{N}}$} & \multicolumn{2}{|r|}{$1-6$ months } & \multicolumn{2}{|c|}{ 7-12 months } & \multicolumn{2}{|c|}{ Overall } \\
\hline & & & 306 & & 194 & & 306 \\
\hline & Patient-time (years) & & 117.3 & & 80.2 & & 509.3 \\
\hline SOC & PT & $\mathrm{n}$ & $\begin{array}{c}\text { Rate } \\
(95 \% \mathrm{Cl})\end{array}$ & $\mathrm{n}$ & $\begin{array}{c}\text { Rate } \\
(95 \% \mathrm{Cl})\end{array}$ & $\mathrm{n}$ & $\begin{array}{c}\text { Rate } \\
(95 \% \mathrm{Cl})\end{array}$ \\
\hline All & All & 33 & $\begin{array}{c}28.1 \\
(19.1-41.5)\end{array}$ & 4 & $\begin{array}{c}5.0 \\
(1.9-13.2)\end{array}$ & 56 & $\begin{array}{c}11.0 \\
(7.9-15.2)\end{array}$ \\
\hline \multirow[t]{2}{*}{$\begin{array}{r}\text { Infections and } \\
\text { infestations }\end{array}$} & All & 7 & $\begin{array}{c}6.0 \\
(2.9-12.4)\end{array}$ & 1 & $\begin{array}{c}1.2 \\
(0.2-8.8)\end{array}$ & 13 & $\begin{array}{c}2.6 \\
(1.4-4.8)\end{array}$ \\
\hline & Pneumonia & 2 & $\begin{array}{c}1.7 \\
(0.4-6.8)\end{array}$ & 1 & $\begin{array}{c}1.2 \\
(0.2-8.8)\end{array}$ & 4 & $\begin{array}{c}0.8 \\
(0.3-2.1)\end{array}$ \\
\hline \multirow[t]{2}{*}{$\begin{array}{l}\text { Immune system } \\
\text { disorders }\end{array}$} & All & 7 & $\begin{array}{c}6.0 \\
(2.8-12.5)\end{array}$ & 1 & $\begin{array}{c}1.2 \\
(0.2-8.8)\end{array}$ & 11 & $\begin{array}{c}2.2 \\
(1.1-4.1)\end{array}$ \\
\hline & $\begin{array}{l}\text { Haemophagocytic } \\
\text { lymphohistiocytosis }\end{array}$ & 7 & $\begin{array}{c}6.0 \\
(2.8-12.5)\end{array}$ & 1 & $\begin{array}{c}1.2 \\
(0.2-8.8)\end{array}$ & 11 & $\begin{array}{c}2.2 \\
(1.1-4.1)\end{array}$ \\
\hline \multirow{3}{*}{$\begin{array}{l}\text { Injury, poisoning } \\
\text { and procedural } \\
\text { complications }\end{array}$} & All & 5 & $\begin{array}{c}4.3 \\
(1.8-10.2)\end{array}$ & - & - & 9 & $\begin{array}{c}1.8 \\
(0.9-3.4)\end{array}$ \\
\hline & $\begin{array}{l}\text { Infusion related } \\
\text { reaction }\end{array}$ & 1 & $\begin{array}{c}0.9 \\
(0.1-6.0)\end{array}$ & - & - & 2 & $\begin{array}{c}0.4 \\
(0.1-1.6)\end{array}$ \\
\hline & $\begin{array}{l}\text { Injection related } \\
\text { reaction }\end{array}$ & 4 & $\begin{array}{c}3.4 \\
(1.3-9.1)\end{array}$ & - & - & 6 & $\begin{array}{c}1.2 \\
(0.5-2.6)\end{array}$ \\
\hline $\begin{array}{l}\text { Metabolism and } \\
\text { nutrition disorders }\end{array}$ & All & 3 & $\begin{array}{c}2.6 \\
(0.8-7.9)\end{array}$ & - & - & 4 & $\begin{array}{c}0.8 \\
(0.3-2.1)\end{array}$ \\
\hline $\begin{array}{l}\text { Skin and } \\
\text { subcutaneous } \\
\text { tissue disorders }\end{array}$ & All & 3 & $\begin{array}{c}2.6 \\
(0.8-7.9)\end{array}$ & 1 & $\begin{array}{c}1.2 \\
(0.2-8.8)\end{array}$ & 4 & $\begin{array}{c}0.8 \\
(0.3-2.1)\end{array}$ \\
\hline $\begin{array}{l}\text { Blood and lymphatic } \\
\text { system disorders }\end{array}$ & All & 1 & $\begin{array}{c}0.9 \\
(0.1-6.1)\end{array}$ & - & - & 2 & $\begin{array}{c}0.4 \\
(0.1-1.6)\end{array}$ \\
\hline $\begin{array}{l}\text { General disorders } \\
\text { and administration } \\
\text { site conditions }\end{array}$ & All & 1 & $\begin{array}{c}0.9 \\
(0.1-6.1)\end{array}$ & 1 & $\begin{array}{c}1.2 \\
(0.2-8.8)\end{array}$ & 2 & $\begin{array}{c}0.4 \\
(0.1-1.6)\end{array}$ \\
\hline Investigations & All & 2 & $\begin{array}{c}1.7 \\
(0.4-6.8)\end{array}$ & - & - & 2 & $\begin{array}{c}0.4 \\
(0.1-1.6)\end{array}$ \\
\hline $\begin{array}{l}\text { Nervous system } \\
\text { disorders }\end{array}$ & All & 1 & $\begin{array}{c}0.9 \\
(0.1-6.0)\end{array}$ & - & - & 2 & $\begin{array}{c}0.4 \\
(0.1-1.6)\end{array}$ \\
\hline $\begin{array}{l}\text { Surgical and medical } \\
\text { procedures }\end{array}$ & All & 1 & $\begin{array}{c}0.9 \\
(0.1-6.0)\end{array}$ & - & - & 2 & $\begin{array}{c}0.4 \\
(0.1-1.5)\end{array}$ \\
\hline
\end{tabular}

Abbreviations: SAE, serious adverse event; SOC, system organ class; PT, preferred term, MedDRA version 21.1; $\mathrm{N}$, number of patients ever treated with anakinra during the time window irrespectively of the length of any unexposed periods; $95 \% \mathrm{Cl}, 95 \%$ Confidence Interval.

Conclusion: The results of the present study confirm the long-term safety profile of anakinra in SJIA patients and show a decreasing overall incidence rate of AEs over time.

Disclosure of Interests: Gabriella Giancane Grant/research support from: The study was funded by SOBI Swedish, Riccardo Papa Grant/research support from: The study was funded by SOBI Swedish, Sebastian Vastert Grant/ research support from: The study was funded by SOBI Swedish, Francesca Bagnasco Grant/research support from: The study was funded by SOBI Swedish, Joost F. Swart Grant/research support from: The study was funded by SOBI Swedish, Pierre Quartier Grant/research support from: The study was funded by SOBI Swedish, michael hofer Grant/research support from: The study was funded by SOBI Swedish, Jordi Anton Grant/research support from: The study was funded by SOBI Swedish, Sylvia Kamphuis Grant/research support from: The study was funded by SOBI Swedish, Helga Sanner Grant/research support from: The study was funded by SOBI Swedish, Mia Glerup Grant/research support from: The study was funded by SOBI Swedish, Fabrizio De Benedetti Grant/research support from: The study was funded by SOBI Swedish, Elena
Tsitsami Grant/research support from: The study was funded by SOBI Swedish, Agustin Remesal Grant/research support from: The study was funded by SOBI Swedish, Estefania Moreno Ruzafa Grant/research support from: The study was funded by SOBI Swedish, Jaime de Inocencio Grant/research support from: The study was funded by SOBI Swedish, Charlotte Myrup Grant/research suppor from: The study was funded by SOBI Swedish, Chiara Pallotti Grant/research support from: The study was funded by SOBI Swedish, Isabelle Koné-Paut Grant/research support from: The study was funded by SOBI Swedish, Karin Franck-Larsson Employee of: I am employee of SOBI pharmaceutical company, Hakan Malmstrom Employee of: I am employee of SOBI pharmaceutical company, Susanna Cederholm Employee of: I am employee of SOBI pharmaceutical company, Angela Pistorio Grant/research support from: The study was funded by SOBI Swedish, Nico Wulffraat Grant/research support from: The study was funded by SOBI Swedish, Nicolino Ruperto Speakers bureau: NR has received honoraria for consultancies or speaker bureaus ( $<10.000$ USD each) from the following pharmaceutical companies in the past 3 years: Ablynx, Astrazeneca-Medimmune, Bayer, Biogen, Boehringer, Bristol Myers and Squibb, Celgene, Eli-Lilly, EMD Serono, Glaxo Smith and Kline, Hoffmann-La Roche,Janssen, Merck, Novartis, Pfizer, R-Pharma, Sinergie, Sobi and UCB., Consultant of: NR has received honoraria for consultancies or speaker bureaus $(<10.000$ USD each) from the following pharmaceutical companies in the past 3 years: Ablynx Astrazeneca-Medimmune, Bayer, Biogen, Boehringer, Bristol Myers and Squibb, Celgene, Eli-Lilly, EMD Serono, Glaxo Smith and Kline, Hoffmann-La Roche,Janssen, Merck, Novartis, Pfizer, R-Pharma, Sinergie, Sobi and UCB., Grant/ research support from: The IRCCS Istituto Giannina Gaslini (IGG), where NR works as full-time public employee has received contributions (> 10.000 USD each) from the following industries in the last 3 years: BMS, Eli-Lilly, GlaxoSmithKline, F Hoffmann-La Roche, Janssen, Novartis, Pfizer, Sobi. This funding has been reinvested for the research activities of the hospital in a fully independent manner, without any commitment with third parties.

DOI: 10.1136/annrheumdis-2021-eular.1731

\section{OP0165 RISK FOR UVEITIS EVENTS AFTER WITHDRAWAL OF DISEASE MODIFYING ANTIRHEUMATIC DRUGS IN THE TREATMENT OF PATIENTS WITH EXTENDED OLIGOARTHRITIS OR RHEUMATOID FACTOR NEGATIVE POLYARTHRITIS}

J. Klotsche ${ }^{1}$, A. Klein ${ }^{2}$, M. Niewerth ${ }^{1}$, T. Kallinich ${ }^{3}$, D. Windschall ${ }^{4}$ J. P. Haas ${ }^{5}$, F. Weller-Heinemann ${ }^{6}$, T. Hospach ${ }^{7}$, F. Dressler ${ }^{8}$, K. Minden ${ }^{1}$, G. Horneff ${ }^{2}{ }^{1}$ German Rheumatism Research Centre Berlin, a Leibniz Institute, Epidemiology unit, Berlin, Germany; ${ }^{2}$ Asklepios Kinderklinik Sankt Augustin, Department of General Pediatrics, Sankt Augustin, Germany; ${ }^{3}$ Charité - Universitätsmedizin Berlin, Pediatric Pneumology and Immunology, Berlin, Germany; ${ }^{4}$ St Josef-Stift Sendenhorst, Kinder- und Jugendrheumatologie, Sendenhorst, Germany; ${ }^{5}$ Deutsches Zentrum für Kinder- und Jugendrheumatologie, Kinder- und Jugendrheumatologie, Garmisch-Partenkirchen, Germany; ${ }^{6}$ Klinikum Bremen-Mitte gGmbH, Prof.Hess-Kinderklinik, Bremen, Germany; ${ }^{7}$ Olgahospital Stuttgart, Department of Paediatric Rheumatology, Stuttgart, Germany; ${ }^{8}$ Medizinische Hochschule Hannover, Kinderklinik, Hannover, Germany

Background: Juvenile idiopathic arthritis (JIA) associated uveitis is an extra-articular manifestation of the JIA disease that may cause vision-threatening complications and an uncontrolled uveitis may even lead to blindness. Uveitis occurs in up to $20 \%$ of patients with JIA, depending on the JIA category. The majority of patients develop uveitis within the first two years after JIA symptom onset, but uveitis can continue into adulthood.

Objectives: The main objective of this study was to analyze the risk for uveitis events after discontinuing disease-modifying antirheumatic drugs (DMARD) in patients with extended oligoarthritis and rheumatoid factor (RF)-negative polyarthritis.

Methods: Data of the two ongoing multicenter biologic registers: German Biologics in Pediatric Rheumatology (BiKeR) and the Juvenile arthritis Methotrexate/ Biologics long-term Observation (JuMBO) were used to analyze the adverseevent $(A E)$ and events of special interest $(E S I)$ reports about uveitis events during treatment and after discontinuation of DMARDs. Biker started recruitment of children and adolescent patients with JIA exposed to biological (b) or conventional (cs) DMARD's in 2001. The patients were further followed in JuMBO after reaching the age of 18 or transitioning to an adult rheumatologist. Disease characteristics, treatment data, AE's and ESI's were reported by the pediatric or adults rheumatologist, respectively.

Results: A total of 2,041 patients with RF-negative polyarthritis $(n=1,280)$ or extended oligoarthritis $(n=761)$ were included into the analyses. The mean follow-up of this study was 7.6 years (SD 5.3). About half of the patients were enrolled in BiKeR with start of etanercept (1,137, 55.7\%), followed by 635 $(31.1 \%)$ patients with start of methotrexate (MTX) monotherapy or adalimumab (ADA, $n=198,9.7 \%)$. A history of uveitis was reported for $238(11.7 \%)$ patients 
at enrolment in BiKeR. More patients with a history of uveitis treated with ADA were included in BiKeR initiating ADA ( $n=98$ of $238,41.2 \%$ ). Patients with uveitis had a lower age at JIA onset in comparison to patients without uveitis (mean 3.6 (SD 3.0) versus 7.0 (SD 4.5) years). A total of 142 recurrent ( $84 \%$ of 169 ) uveitis events were reported in 93 patients and for 27 patients $(1.3 \%$ of 2,041$)$ was an incident uveitis reported during follow-up. More than one uveitis event was reported for 32 patients with a maximum number of 4 uveitis flares in 3 patients. Nineteen uveitis flares $(11.2 \%$ of 169$)$ were reported for patients after the age of 18 . The longer the time since DMARD discontinuation the fewer uveitis events occurred. Uveitis events were significantly more often reported in the first 24 months after MTX discontinuation (<6 months: OR=3.19, $95 \% \mathrm{Cl}: 1.70$ to 5.96 ; 6 to $<12$ months: $\mathrm{OR}=2.06,95 \% \mathrm{Cl}: 1.01$ to $4.66 ; 12$ to $<24$ months: $\mathrm{OR}=2.20$, $95 \% \mathrm{Cl}: 1.14$ to 4.25 ) and in the first three months after biological DMARD discontinuation (OR=5.4, 95\%Cl: 1.56 to 18.33). Patients with a MTX dose of $\leq 10 \mathrm{mg} /$ $\mathrm{m}^{2}$ at last MTX intake had a higher likelihood for uveitis events $(\mathrm{OR}=1.40,95 \% \mathrm{Cl}$ : 1.02 to 1.92$)$.

Conclusion: This is the first study that analyzed the risk of uveitis after DMARD withdrawal. Uveitis relapses are common. Patients who discontinued DMARD therapy were at high risk for uveitis within the first 3 to 24 months after discontinuation. Rheumatologists and ophthalmologists should be aware about this risk which should lead to a regular uveitis screening after DMARD withdrawal.

Disclosure of Interests: Jens Klotsche: None declared, Ariane Klein: None declared, Martina Niewerth: None declared, Tilmann Kallinich: None declared, Daniel Windschall: None declared, Johannes-Peter Haas: None declared, Frank Weller-Heinemann Speakers bureau: Pfizer, Abbvie, SOBI, Roche, Novartis, Ton Hospach: None declared, Frank Dressler: None declared, Kirsten Minden: None declared, Gerd Horneff: None declared

DOI: 10.1136/annrheumdis-2021-eular.4014

\section{OP0166 \\ DISEASE ACTIVITY IN CHILDREN WITH JUVENILE IDIOPATHIC ARTHRITIS AFTER SIMULTANEOUS PCV13 AND HIB VACCINATION: A COHORT STUDY}

O. Lomakina ${ }^{1}$, E. Alexeeva ${ }^{1,2}$, T. Dvoryakovskaya $^{1}, \mathrm{~K}$. Isaeva ${ }^{1}$

A. Chomakhidze ${ }^{1}$, R. Denisova ${ }^{1}$, A. Mamutova ${ }^{1}$, A. Fetisova ${ }^{1}$, M. Gautier ${ }^{1}$ K. Chibisova ${ }^{1}$, D. Vankova ${ }^{1}$, E. Krekhova ${ }^{1,2}$, M. Shingarova ${ }^{2}$, I. Kriulin ${ }^{1,2}$ I. Tsulukiya ${ }^{1}$, I. Zybkova ${ }^{1}$, N. Tkachenko ${ }^{1}$. 'National Medical Research Center of Children's Health, Department of Rheumatology, Moscow, Russian Federation; ${ }^{2}$ Sechenov First Moscow State Medical University (Sechenov University), Pediatrics and pediatric rheumatology, Moscow, Russian Federation

Background: The safety of vaccination of children with rheumatic diseases is determined not only by the risk of adverse events but also by the risk of exacerbation of the disease. The simultaneous administration of several vaccines can increase the likelihood of these events.

Objectives: To evaluate the clinical and laboratory signs of disease activity in children with juvenile idiopathic arthritis (JIA) after simultaneous vaccination against pneumococcal and Haemophilus influenzae type b (Hib) infections.

Methods: We included hospitalized patients with JIA ages 2 through 18 without serious comorbidity, immunized with polysaccharide conjugate vaccines against pneumococcal (PCV13) and Hib infections. Vaccines were administered $(0.5 \mathrm{ml}$ each) concurrently subcutaneously into the deltoid area. In all children before and 3 weeks after vaccination, clinical (joints with active arthritis, uveitis activity) and laboratory signs (increased ESR, concentrations of highly sensitive C-reactive protein - hsCRP, and calprotectin) of JIA activity were assessed. Serum hsCRP and calprotectin were quantified by ELISA. The upper limit of the reference interval for hsCRP was considered (according to the manufacturer's instructions) a value of $8.2 \mathrm{mg} / \mathrm{L}$, for calprotectin $-2.9 \mu \mathrm{g} / \mathrm{ml}$, and for ESR $->10 \mathrm{~mm} / \mathrm{h}$.

Results: The study included 430 patients with JIA (girls $60.9 \%$ ), median (IQR) age -11.1 years (7.3 to 14.4 ), onset of JIA -4.7 years (2.4 to 8.6). Patients with persistent oligoarticular JIA numbered 149 (34.7\%), polyarticular RF-negative - 148 (34.4\%), systemic - 101 (23.4\%), enthesitis-related - 20 (4.7\%), and polyarticular RF-positive JIA - 12 (2.8\%). Biologic disease-modifying antirheumatic drugs (DMARDs) were administered to 278 (64.7\%), non-biologic DMARDs (mostly methotrexate) $-282(65.6 \%)$, corticosteroids $-45(10.5 \%)$, and NSAIDs - $18(4.2 \%)$ patients. Three weeks after vaccination, out of $100(23.3 \%)$ patients with initially active joints, signs of active arthritis remained in 96 patients, of which 16 patients had a decrease in the median (IQR) number of active joints by 4 ( 2 to 8). Among patients without active joints at baseline, signs of active arthritis were not subsequently detected. Before vaccination, 9 patients had uveitis in the exacerbation phase, 7 - in the subactive phase, and 41 - in the remission phase. After vaccination, exacerbation of uveitis persisted in 4 patients. There were no new cases of uveitis or its exacerbation. The dynamics of laboratory signs of JIA activity are presented in Table 1. Initially, the high concentration of calprotectin was found in 191 (44.4\%) patients, and after vaccination - in 220 (51.2\%) patients; the difference was $6.7 \%(95 \% \mathrm{Cl} 1.0-12.5)$; hsCRP - in $34(7.9 \%)$ and $51(11.9 \%)$ patients; the difference was $4.0 \%(95 \% \mathrm{Cl} 0.6$ - 7.3$)$; high ESR - in $76(17.7 \%)$ and
$41(9.5 \%)$ patients; the difference was $-8.1 \%(95 \% \mathrm{Cl}-11.6$ to -4.7$)$, respectively. An independent predictor of new cases of high concentration of hsCRP $(n=36)$, but not new cases of high concentration of calprotectin $(n=94)$, was the initial number of joints with active arthritis - odds ratio 2.37 (95\% Cl $1.14-4.93)$.

Table 1. Laboratory signs of JIA activity after simultaneous administration of vaccines against pneumococcal (PCV13) and Hib-infections

\begin{tabular}{|c|c|c|c|c|}
\hline \multirow[b]{2}{*}{ Variables } & Baseline & After 3 weeks & \multirow[b]{2}{*}{ Ratio* } & \multirow[b]{2}{*}{$\mathbf{p}^{\star *}$} \\
\hline & \multicolumn{2}{|c|}{ Geometric mean $(95 \% \mathrm{Cl})$} & & \\
\hline Calprotectin, $\mu \mathrm{g} / \mathrm{ml}$ & $2.93(2.70-3.17)$ & $3.15(2.92-3.40)$ & $1.08(0.99-1.17)$ & 0.087 \\
\hline hsCRP, mg/L & $0.69(0.60-0.78)$ & $0.79(0.69-0.90)$ & $1.15(0.99-1.33)$ & 0.073 \\
\hline $\mathrm{ESR}, \mathrm{mm} / \mathrm{h}$ & $4.4(4.0-4.8)$ & $3.7(3.4-4.0)$ & $0.84(0.78-0.90)$ & 0.001 \\
\hline
\end{tabular}

Note. $\mathrm{Cl}$ - confidence interval. * Ratios of paired observations $(95 \% \mathrm{Cl}) .{ }^{* *} \mathrm{P}$-value calculated in paired samples t-test.

Conclusion: Simultaneous vaccination against pneumococcal (PCV13) and Hib-infections in children with JIA produced no negative dynamics of the traditional indicators of disease activity (joint activity, uveitis, high ESR). At the same time, 3 weeks after vaccination, an increase in the concentration of calprotectin and hsCRP was found in a small number of patients $(<10 \%)$.

Disclosure of Interests: None declared

DOI: 10.1136/annrheumdis-2021-eular.3457

\begin{tabular}{|l|l}
\hline OP0167 & THE ROLE OF LUNG ULTRASOUND IN THE \\
DIAGNOSIS OF INTERSTITIAL LUNG DISEASE IN \\
CHILDREN WITH DERMATOMYOSISTIS
\end{tabular}

R. Dertkgil ${ }^{1}$, C. Cappello ${ }^{1}$, S. Dertkigil ${ }^{1}$, R. Marini ${ }^{2}$, S. Appenzeller ${ }^{3} .{ }^{1}$ UNICAMP, Radiology, Campinas, Brazil; ${ }^{2}$ UNICAMP, Pediatrics, Campinas, Brazil;

${ }^{3}$ UNICAMP, Orthopedics, Rheumatology and Traumatology, Campinas, Brazil

Background: Dermatomyositis is a multi organ autoimmune disease wich is commonly complicated with interstitial lung disease. Chest high-resolution computed tomography (HRCT) is still considered the diagnostic gold standard for interstitial lung disease and is quantification, however he increasing use of lung ultrasound may play an important role in the future.

Objectives: The aim of our study was to determine the diagnostic value of lung ultrasound in the detection and progression of interstitial pulmonary disease in patients with dermatomyositis.

Methods: Twenty two subjects with dermatomyositis diagnosed according to the American College of Rheumatology criteria were enrolled ( 6 males, 16 females; mean age: $15,8 \pm 8.8$ years; range: 6 to 29 years). All subjects underwent high resolution computed tomography followed by transthoracic ultrasound for comet tail sign detection and pleural irregularity in order to predict the degree of interstitial lung disease. The modified transthoracic ultrasound assessment was performed at 06 thoracic regions each side. The Warrick score was calculated according standard high-resolution chest computed tomography images that were evaluated independently from each other by two thoracics radiologists.

Results: A significantly positive correlation between transthoracic ultrasound and the severity of pulmonary involvement, as seen by the number of B lines (Spearman 's correlation coefficient $=0.80, p<0.001$ ), and the number of positive areas (regions wih more than $3 \mathrm{~B}$ lines) (Spearman 's correlation coefficient $=0.75$, $\mathrm{p}<0.001$ ) were found. When compared with high-resolution chest computed tomography as the gold standard method, the sensitivity, specificity, of transthoracic ultrasound was $96.4 \%, 83,3 \%$ respectively. Addicionally the number of $\mathrm{B}$ lines (sum of 35 or more $B$ lines) and a number of B lines positive areas ( 7 or more regions with at least $3 \mathrm{~B}$ lines) cut of allowed to discriminate the inflamatory pattern (ground glass) to those with structural pattern (honeycomb and pulmonary cysts)

Conclusion: Our study showed that transthoracic ultrasound comet tails scoring system could be useful in the assessment of the pulmonary involvement in patients with dermatomyositis, and should be considered as a primary screening exam to exclude lung involvement, rather than routine chest CT scans in assimptomatic patients.

Disclosure of Interests: None declared

DOI: 10.1136/annrheumdis-2021-eular.4033

\section{OP0168 IN DEFICIENCY OF ADENOSINE DEAMINASE 2}

U. Kaya Akca ${ }^{1}$, E. Sag2, Ş. Ünal ${ }^{3}$, M. Kasap-Cuceoglu2, Y. Bilginer2, S. Özen2. ${ }^{1}$ Hacettepe University School of Medicine, Pediatric Rheumatology, Ankara, Turkey; ${ }^{1}$ Hacettepe University School of Medicine, Pediatric Rheumatology, Ankara, Turkey; ${ }^{3}$ Hacettepe University School of Medicine, Pediatric Hematology, Ankara, Turkey 